\title{
3 \\ Tax, Inequality and Challenges for the Future
}

\author{
John Passant ${ }^{1}$
}

\section{Introduction}

As in most countries in the developed world, inequality in Australia has been growing for more than three decades. ${ }^{2}$ In part this is due to systemic issues associated with the relative power of capital and labour and the decline in the share of national factor income going to labour. ${ }^{3}$ In part it has to do with deliberate government policy. In a nutshell, growing inequality undermines the meritocracy on which democracy depends. It creates a sense of unfairness and disillusionment with society, both politically and economically, concentrating more wealth and power in the hands of already powerful and wealthy people. It corrupts or can corrupt institutions and, as the past 30 or so years have shown, can undermine

1 Lecturer, Business School, Charles Darwin University; PhD candidate, School of Politics and International Relations, ANU. This research is supported by an Australian Government Research Training Program (RTP) Scholarship.

2 Australian Council of Social Service (ACOSS), Inequality in Australia 2015: A Nation Divided (Sydney, 2015) 8, www.acoss.org.au/wp-content/uploads/2015/06/Inequality_in_Australia_ FINAL.pdf (viewed 24 April 2016).

3 Factor income is the income arising from the factors of production - land, labour and capital. For the changes in shares over time, see Australian Bureau of Statistics (ABS), 'Income at Current Prices, December Quarter 2015' in ABS, 5206.0 - Australian National Accounts: National Income, Expenditure and Product, Dec 2015, www.abs.gov.au/ausstats/ abs@.nsf/Latestproducts/5206.0Main\%20Features4Dec\%202015?opendocument $\&$ tabname= Summary\&prodno=5206.0\&issue $=$ Dec\%202015\&num $=\& v i e w=($ viewed 26 April 2016) . 
both directly and indirectly those institutions and policies aimed at redistributing wealth from the rich to the less well off. In addition, growing inequality creates economic instability because it undermines the capacity of those in lower income brackets to consume the products of the top income earners and wealth holders. As Sheil and Stilwell say: 'The deep-seated economic inequalities also have major social and political consequences. They fracture social cohesion and create power imbalances that can undermine the nominally democratic institutions. ${ }^{\text {.4 }}$

Tax reform - or what I have elsewhere described as neoliberal tax reform ${ }^{5}$ - has contributed to that increasing inequality. ${ }^{6}$ Australia's tax system has become less and less progressive over time. ${ }^{7}$ The tax base has shifted to some extent from income to consumption, and the income tax system itself is less progressive. Over time, tax rates have decreased, for individuals and for companies. In addition, the creation of tax expenditures such as a range of superannuation-related taxation concessions and the capital gains tax concessions, among others, favour and benefit those in the richer and wealthier strata of society. ${ }^{8}$

While income inequality has grown in Australia, wealth remains concentrated in the hands of those at the top. As ACOSS puts it: 'The top $10 \%$ of households own $45 \%$ of all wealth, most of the remainder

4 Christopher Sheil and Frank Stilwell, The Wealth of the Nation: Current Data on the Distribution of Wealth in Australia (Evatt Foundation 2016), evatt.org.au/files/files/The\%20Wealth\%20of\%20 the\%20Nation.pdf (viewed 16 July 2016).

5 John Passant, 'Neoliberalism in Australia and the Henry Tax Review' (2013) 8(1) The Journal of the Australasian Tax Teachers Association 117, www.business.unsw.edu.au/About-Site/SchoolsSite/Taxation-Business-Law-Site/Journal\%20of\%20The\%20Australasian\%20Tax\%20Teachers\%20 Associati/JATTA_8-1_2014.pdf (viewed 28 April 2016).

6 See, for example, Bob Douglas, Sharon Friel, Richard Denniss and David Morawetz, Advance Australia Fair? What to Do About Growing Inequality in Australia (Australia21, 2014) 17, gallery. mailchimp.com/d2331cf87fedd353f6dada8de/files/1b2c7f48-928f-4298-81db-cf053a224320.pdf (viewed 3 May 2016).

7 Organisation for Economic Cooperation and Development (OECD), Divided We Stand: Why Inequality Keeps Rising - Country Note: Australia (Paris 2011) 1, www.oecd.org/australia/49177643. pdf (viewed 3 May 2016); Andrew Leigh, Battlers and Billionaires: The Story of Inequality in Australia (Redback Press, 2013) 77; Neil Brooks, 'Taxing the Wealthy' in Chris Evans, Richard Krever and Peter Mellor (eds), Australia's Future Tax System: The Prospects After Henry (Thomson Reuters, Sydney 2010) 197, 202.

8 The superannuation concessions and the capital gains discount tax expenditures, together with rental property negative gearing, total according to the Treasury about $\$ 40$ billion in revenue forgone annually, of which the superannuation concessions make up about $\$ 30$ billion. For a compilation of the more than $\$ 100$ billion worth of tax expenditures (i.e. disguised grants through the tax system), see The Treasury, 'Tax Expenditure Statement 2015' (Canberra, January 2016), www.treasury.gov.au/ PublicationsAndMedia/Publications/2016/TES-2015 (viewed 4 May 2016). 
of wealth is owned by the next $50 \%$ of households, while the bottom $40 \%$ of households own just $5 \%$ of all wealth'. ${ }^{9}$ More recent analysis suggests the top 10 per cent of households own more than 50 per cent of all wealth. ${ }^{10}$ Writing for the Evatt Foundation, Sheil and Stilwell argue that increasing inequality is deepening two rifts within society. They say:

This affluent elite - the Top $10 \%$ and especially the Top $1 \%$ - is getting cumulatively richer, not only relative to poor households but also, significantly, in relation to the next $50 \%$ of households. Two fault lines are widening - between the bottom $40 \%$ and the rest, and between the Top $10 \%$ and the $50 \%$ in the middle.

They are not alone in their disquiet. Thomas Piketty, Joseph Stiglitz, Richard Wilkinson and Kate Pickett, Neil Brooks, Andrew Leigh and ACOSS have all, among many others, raised concerns that this growing disparity of income and wealth threatens social stability and economic performance, and is even a threat to democracy. ${ }^{11}$

Tax won't address the fundamental inequality between capital and labour, but it can ameliorate that inequality. The suggestions in this chapter of a net wealth tax and minimum taxes on wealthy individuals and big business are made in light of the fact that by OECD standards Australia is a low tax country, ${ }^{12}$ and understanding that about 2.99 million citizens in 2013-14 lived in poverty, including 731,300 children. ${ }^{13}$ These proposals have the capacity to contribute to the lessening of inequality and poverty.

Reintroducing equity into the tax debate means considering, among other things, wealth taxes, ways to make the current income tax system more progressive (including higher tax rates at higher income levels and addressing tax expenditures that favour well-off taxpayers), and revisiting taxes on all economic rent (that is, not limiting tax to resource rents).

9 ACOSS, above n 2, 31.

10 Sheil and Stilwell, above $\mathrm{n}$ 4, in the Overview, not page numbered.

11 Thomas Piketty, Capital in the Twenty-First Century (The Belknap Press of Harvard University Press, Cambridge, Massachusetts, 2014); Joseph E Stiglitz, The Price of Inequality (Penguin Books Ltd, London, 2012); Richard Wilkinson and Kate Pickett, The Spirit Level: Why Greater Equality Makes Societies Stronger (2009, Bloomsbury Press, New York); Neil Brooks, 'Taxing the Wealthy' in Chris Evans, Richard Krever and Peter Mellor, Australia's Future Tax System: The Prospects After Henry (Thomson Reuters, Sydney 2010) 197; Andrew Leigh, Battlers and Billionaires: The Story of Inequality in Australia (Black Inc, Collingwood, 2013), ACOSS above n 2, 8.

12 OECD Centre for Tax Policy and Administration, Revenue Statistics 2015 - Australia (OECD, 2015), www.oecd.org/tax/revenue-statistics-australia.pdf (viewed 2 May 2016).

13 Social Policy Research Centre and ACOSS, Poverty in Australia 2016 (Strawberry Hills, 2014) 5, www.acoss.org.au/wp-content/uploads/2016/10/Poverty-in-Australia-2016.pdf (viewed 6 April 2017). 
Rethinking ways to deal with the low tax burdens of big business could be part of that discussion. Pollution and financial transaction taxes could also be part of any wide ranging tax reform discussion and debate.

These are just a few reform proposals we could investigate. We are limited only by our own imaginations and the power of capital and the rich. Given space constraints, this chapter deals with just two of the proposals. The first is a Buffett rule for individuals and companies. The second is a wealth tax.

\section{A Buffet Rule for Individuals and Companies?}

\section{A. Individuals}

Warren Buffett was shocked to learn that his average tax rate was lower than that of his secretary. ${ }^{14}$ This was because, for example, his business deductions, exemptions, offsets (credits), concessional taxation of some activities and deferral of liability reduced his taxable income. Many of these are deviations from accounting norms and the benchmark tax base. Such deviations from the tax benchmark are known as tax expenditures. ${ }^{15}$ The Treasury explains this benchmark against which to judge income tax expenditures in this way:

The tax base for the income tax benchmark is based on the Schanz-HaigSimons definition of income. An entity's income is defined as the increase in the entity's economic wealth (stock of assets) between two points in time, plus the entity's consumption in that period. Consumption includes all expenditures except those incurred in earning or producing income.

In other words, a buck is a buck is a buck and should be taxed in the same way irrespective of the nature of the gain or who made it.

14 The National Economic Council, The Buffett Rule: A Basic Principle of Tax Fairness (Washington, April 2012), obamawhitehouse.archives.gov/blog/2012/04/10/white-house-reportbuffett-rule-basic-principle-tax-fairness (viewed 2 May 2016).

15 The Treasury, Tax Expenditure Statement 2015 (Canberra 2016) 3, www.treasury.gov.au/ / media/Treasury/Publications\%20and\%20Media/Publications/2016/Tax\%20Expenditures\%20 Statement\%202015/Downloads/PDF/2015_TES.ashx (viewed 2 May 2016). 
The Buffett rule attempts to recoup some of those tax expenditures by imposing a tax liability based on gross income, not taxable income. For example, in 2012 it was reported that President Obama 'proposed the Buffett Rule as a basic rule of tax fairness that should be met in tax reform. To achieve this principle, the President ... proposed that no millionaire pay less than $30 \%$ of their income in taxes. ${ }^{16}$

The President is not alone. The Greens in Australia have suggested a Buffett rule of 35 per cent of the gross income of those individuals whose gross income is $\$ 300,000$ or more, while the Labor Party Opposition appears split on the issue. ${ }^{17}$ The Greens proposed \$300,000 threshold covers the top 1 per cent of income earners; ${ }^{18}$ they use as an example the case of 56 millionaires with gross income in total of $\$ 129$ million who, through deductions, reduced their taxable income to below the taxfree threshold of $\$ 18,200$ and hence paid no income tax. ${ }^{19}$ Among the deductions claimed by the 56 was $\$ 47$ million for tax advice. ${ }^{20} \mathrm{~A}$ Buffett rule at the level the Greens propose would recoup 35 per cent of their $\$ 129$ million gross revenue or $\$ 45.15$ million. There will be many more well off taxpayers caught by such a rule and yielding much more revenue for the Commonwealth.

A Buffett rule conflicts with general tax principles. Under such principles, taxable income equals assessable income less allowable deductions. The appropriate tax rate is then applied to this net amount. The tax to be paid can then be reduced by any offsets (such as franking credits and foreign tax credits). In part, what a Buffett rule does is recoup the tax expenditures (in the Greens' example, the deductibility of tax advice) built into the tax system. Even if the tax reduction occurs not because of tax expenditures but, for example, as a result of 'legitimate' benchmark appropriate deductions, the Buffett rule accepts that such a large gross revenue requires some contribution back to society because it arises from society, and that people with incomes of $\$ 300,000$ or more a year have a capacity to pay (or borrow to pay) despite their non-taxable or low tax status for the income year in question.

16 The National Economic Council, above n 14, 1.

17 The Greens, 'Buffett Rule: A High-Income Tax Guarantee', greens.org.au/buffett-rule (viewed 3 May 2016); Katherine Murphy, 'Labor Faces Internal Wrangle Over "Buffett rule" to Stop Wealthy Avoiding Tax', The Guardian Australia 4 April 2017, www.theguardian.com/australia-news/2017/apr/04/ labor-faces-internal-wrangle-over-buffett-rule-to-stop-wealthy-avoiding-tax (viewed 6 April 2017).

18 The Greens, above n 17, 1.

19 Ibid.

20 Ibid. 


\section{B. A Buffett rule for big business?}

The same arguments apply to big business. In December 2016 the Commissioner of Taxation released the Corporate Tax Transparency Report for the 2014-15 Income Year. It covers public companies with a turnover of more than $\$ 100$ million and $\$ 200$ million for private companies. The report shows that 679 , or 36 per cent, of the 1,904 entities in the target group paid no income tax in the 2014/2015 income year. ${ }^{21}$ There are, as the report points out, a range of reasons why the big businesses in question paid no income tax, including market conditions, use of previous year tax losses, offsets and the like. Tax expenditures and tax avoidance are only part of the explanation.

However, we can look at this from another angle. A Buffett rule for companies can be seen as the Australian Government, on behalf of the Australian people, imposing an operating fee on big business to allow it to pursue its profit-seeking activity in Australia. The fee would be a ground rent imposed on business for the ability or potential to derive profit from Australian workers and consumers. Such a fee or tax could apply not just to companies who paid no income tax but also to those with a low effective tax rate. ${ }^{22}$ On top of the non-taxable companies, there are many 'low tax' companies; a Tax Justice Network/United Voice study of the ASX top 200 companies, for example, found that one-third of those companies have an effective tax rate of less than 10 per cent. ${ }^{23}$

It is a valid criticism that a Buffett rule for companies would undermine the intent and actuality of the tax expenditures that allow deductions, offsets or exemptions outside the benchmark. However, the equitable and socially responsible response must be that those with very large gross

21 Australian Taxation Office, Corporate Tax Transparency Report for the 2014-15 Income Year (Canberra, 2017), www.ato.gov.au/business/large-business/in-detail/tax-transparency/corporatetax-transparency-report-for-the-2014-15-income-year/?page=5\#Net_losses_and_nil_tax_payable (viewed 6 April 2017).

22 For an argument in favour of royalties on resource companies as a substitute for this, see John Passant, 'Taxing Resource Rents in Australia - What a Capital Idea'. A draft is available here: www.researchgate.net/publication/292149294_Taxing_resource_rents_in_Australia_-_what_a_ capital_idea (viewed 5 May 2016). A company's effective tax rate is the amount of tax actually paid as a percentage of accounting (not taxable) income. A revised version of this article will be published in 2017 in the Journal of Australian Political Economy.

23 United Voice and the Tax Justice Network, Who Pays for Our Common Wealth? Tax Practices of the ASX 200 (Melbourne, 2014) 21, www.unitedvoice.org.au/news/who-pays-our-common-wealth (viewed 4 May 2016). 
incomes can afford to contribute to Australian society and the winding back of such tax expenditures is a limit on those expenditures, not their abolition.

The fee or tax could, for example, be a percentage of a company's gross revenue from Australian sources, reducing as the company's effective tax rate approaches the company tax rate of 30 per cent. Estimates are that the untaxed gross income of big public companies and foreign private entities revealed by the Commissioner of Taxation's Corporate Tax Transparency Report is $\$ 462$ billion. ${ }^{24}$ A 3 per cent tax on that gross income would yield over $\$ 13$ billion in income from those 679 companies. ${ }^{25}$ The same fee-based ground rent approach could apply to those big businesses with an effective tax rate of 10 per cent or less, at the rate say of 2 per cent of the gross revenue, and similarly a rate of 1 per cent for those big businesses with effective tax rates between 10 and say 20 per cent.

Let's now turn to wealth taxes.

\section{Wealth Taxes}

In Capital in the Twenty-First Century, ${ }^{26}$ Thomas Piketty - to use the words of a roundtable on inequality in Australia - suggested 'that the most powerful force pushing in the direction of growing inequality is the tendency of the rate of return on capital " $r$ " to exceed the rate of growth of output "g"'. ${ }^{27}$ For the reasons mentioned in the first paragraph of this

24 Richard O’Brien, 'Turnbull \& Morrison Tax Consultants', The Australian Independent Media Network, 11 December 2016, theaimn.com/turnbull-morrison-tax-consultants/ (viewed 6 April 2017); for the 2013-14 Report issued December 2015, the estimate was $\$ 405.9$ billion of gross revenue that was untaxed for public companies alone. See Nassim Khadem and Craig Butt, 'Which of Australia’s Biggest Companies Are Not Paying Tax', The Sydney Morning Herald 17 December 2015, www.smh.com.au/business/the-economy/which-of-australias-biggest-companies-are-not-paying-tax20151216-glpl3a.html (viewed 4 May 2016).

25 The figure does not include the 30 per cent of private Australian companies in the target group who paid no income tax. ATO, Corporate Tax Transparency Report for the 2013-14 Income Year (Canberra 2016), www.ato.gov.au/Business/Large-business/In-detail/Tax-transparency/Corporatetax-transparency-report-for-the-2013-14-income-year/ (viewed 4 May 2016).

26 Thomas Piketty, Capital in the Twenty-First Century (The Belknap Press of Harvard University Press, Cambridge, Massachusetts, 2014).

27 Bob Douglas et al, above n 6, 21. In my view Piketty misunderstands the nature of capitalism in that he fails to differentiate between the means of production (and ownership of such) and other assets. At page 52 he dismisses Marx's law of the tendency of the rate of profit to fall as 'quite wrong'. The law is based on the labour theory of value, and in my view is an excellent way of understanding the shift in wealth and income from labour to capital as one countervailing tendency to address the law. 
chapter, this systemic and increasing inequality of income and wealth threatens both growth and democracy. ${ }^{28}$ To address this, Piketty argues for a progressive global tax on capital ${ }^{29}$ in conjunction with financial transparency. ${ }^{30} \mathrm{He}$ sees a global wealth tax as both a counterweight to increasing concentrations of wealth (and, as a consequence, declining democracy) and as a spur for greater fiscal openness and transparency. ${ }^{31}$ By 'capital' Piketty essentially means assets, irrespective of whether they are productive or not. Specifically, Piketty suggests 0 per cent tax for net assets below $€ 1$ million, 1 per cent between $€ 1$ million and $€ 5$ million and 2 per cent above that. ${ }^{32} \mathrm{He}$ also suggests consideration of much higher rates - in the order of 5 per cent or 10 per cent - for the super wealthy, those with assets greater than $€ 1$ billion. ${ }^{33}$

While Piketty recognises that the global cooperation needed for this tax renders the proposal utopian, he argues it is nevertheless useful as both a benchmark and to help countries and regions (such as the European Union) to move incrementally towards this goal. ${ }^{34}$ Let's be utopian and incremental. Australia could begin the taxation of wealth process that other countries could then follow. Since the top 10 per cent own 45 per cent of Australia's wealth, ${ }^{35}$ and given that Australia's net wealth is about $\$ 10$ trillion, ${ }^{36}$ the top 10 per cent own about $\$ 4.5$ trillion. A 1 per cent annual wealth tax on that group would yield about $\$ 45$ billion annually. Further, the minimum net worth of the top 1 per cent is over $\$ 5$ million each. ${ }^{37}$ As there are 90,000 people in the top 1 per cent, a net wealth tax of 2 per cent would raise as a minimum well over $\$ 9$ billion. The amount is likely to be much higher: using the Evatt Foundation figures mentioned above, the top 1 per cent of households own more than 15 per cent of Australia's wealth, which means in concrete terms they own more than

\footnotetext{
28 Ibid.

29 Thomas Piketty, above n 26, 515.

30 Ibid. 518.

31 Ibid. 527.

32 Ibid. 517.

33 Ibid.

34 Ibid. 515.

35 ACOSS, above n 2, 31.

36 Philip Lowe, 'National Wealth, Land Values and Monetary Policy', address by Philip Lowe, Deputy Governor of the Reserve Bank of Australia, to the 54th Shann Memorial Lecture, Perth, 12 August 2015, 3, www.bis.org/review/r150812f.pdf (viewed 4 May 2016).

37 Douglas et al, above n 6, 14 .
} 
$\$ 1.5$ trillion of assets here. On those figures a 1 per cent wealth tax on the wealth of the top 1 per cent would yield $\$ 15$ billion annually and a 2 per cent tax would bring in about $\$ 30$ billion.

One argument Piketty uses for net wealth taxes is that, apart from helping to reclaim democracy and citizen participation in society through redistributive policies, wealth is a better indicator of capacity to pay than income. ${ }^{38}$ Further, net wealth taxes will see an increase in productive investment into assets capable of producing adequate income returns to pay the tax. ${ }^{39}$ In addition, a global wealth tax can exist only in an environment of fiscal transparency, and such transparency would clear up the opaque nature of wealth ownership and allow a more rational debate about, for example, the social state, addressing climate change, and global poverty. ${ }^{40}$

An alternative to an annual net wealth tax is, as the Henry Tax Review, Neil Brooks and the Australia Institute suggest, a tax on net wealth transfers on death. ${ }^{41}$ Inter-state tax competition, driven by then Queensland Premier Joh Bjelke-Petersen, destroyed estate and gift duties in Australia in the 1970s when Queensland abolished such taxes and the other states and the Commonwealth responded quickly by also abolishing theirs. The reintroduction of such duties on, for example, the top 1 per cent of wealth holders (that is, those with estates greater than $\$ 5$ million), at rates which recognise that such intergenerational transfers occur only once, would tax the 'undeserving rich'. ${ }^{42}$ It could be structured so as to provide the equivalent, over time, of an annual net wealth tax, ${ }^{43}$ thereby providing funds to help address to some extent further growth in inequality through, for example, increases in social welfare payments and establishing new or strengthening existing institutions of governance that restrain the market and empower the less powerful. ${ }^{44}$ However, as Piketty argues, a progressive

\footnotetext{
38 Piketty, above n 26, 526.

39 Ibid.

40 Ibid. 519.

41 Australian Government, Australia's Future Tax System: Report to the Treasurer, Part Two: Detailed Analysis, Vol 1 (AGPS, Canberra December 2009), 137; Neil Brooks, 'Taxing the Wealthy' in Chris Evans, Richard Krever and Peter Mellor, Australia's Future Tax System: The Prospects After Henry (Thomson Reuters, Sydney 2010) 197, 223ff; David Richardson, Surprise Me When I'm Dead: Revisiting the Case for Estate Duties (The Australia Institute, February 2016), www.tai.org.au/sites/ defualt/files/Revisiting\%20the\%20Case\%20for\%20Estate\%20Duties.pdf (viewed 9 May 2017).

42 Neil Brooks, 'Taxing the Wealthy' in Chris Evans, Richard Krever and Peter Mellor, Australia's Future Tax System: The Prospects After Henry (Thomson Reuters, Sydney 2010) 197, 206.

43 Thomas Piketty, above n 26, 374.

44 Neil Brooks, above n 42, 223ff.
} 
annual global tax on wealth is but one of a suite of progressive taxes to achieve this aim and other aims. ${ }^{45}$ For Piketty, the tax is not so much about financing the social state on its own as about addressing growing inequality and, to avoid future economic crisis, regulating the financial and banking systems; it is about regulating capitalism. ${ }^{46}$

\section{Conclusion}

A Buffett rule for individuals and companies, and a wealth tax, are but two reforms among many that would make the overall tax system more equitable. Powerful, very wealthy forces and the democratic institutions they dominate are, as the history of the last 40 years or so globally shows, pushing in the direction of greater and greater freedom for market forces, resulting in greater and greater inequality. This means that at the present juncture in human history the two proposals I have proffered will not be taken up. Nevertheless these two measures, among a range of other tax and non-tax prescriptions, would help policymakers address growing inequality and the threat that poses to our democracy and economy.

45 Thomas Piketty, above n 26, 518.

46 Ibid. 
This text is taken from New Directions for Law in Australia: Essays in Contemporary Law Reform, edited by Ron Levy, Molly O’Brien, Simon Rice, Pauline Ridge and Margaret Thornton, published 2017 by ANU Press, The Australian National University, Canberra, Australia. 